\title{
Family Perception of the Process of Organ Donation. Qualitative Psychosocial Analysis of the Subjective Interpretation of Donor and Nondonor Families
}

\author{
Jorge S. López Martínez, María Jesús Martín López, \\ Barbara Scandroglio, and José Manuel Martínez García \\ Universidad Autónoma de Madrid
}

\begin{abstract}
Family perception of organ donation has been explored by numerous authors using statements by the people who decided whether or not to donate the organs of a relative in a situation of brain death. Within this tradition, in this work, we analyze the discourse of six families who granted permission for organ donation and three who refused. We describe the process-based interpretation of this experience and identify psychosocial variables and processes that further our understanding of the decision finally adopted. We have identified two heuristics that guide family decision when organ donation is requested: the explicit or inferred will of the deceased and family attitudes to organ donation and transplant. It is postulated that the interaction of these two factors explains a large amount of the decisions made. We also hypothesize that a marked discrepancy between these two factors increases the importance of other aspects, especially the role of the transplant coordinator and of other healthcare personnel. These results support, at a social level, the implementation of transplant promotion programs; and at a healthcare level, the combined use of techniques of crisis intervention and attitude change.
\end{abstract}

Keywords: qualitative study, organ donation, perception, families, interview

\begin{abstract}
El estudio de la percepción familiar sobre donación de órganos ha sido abordado por numerosos autores partiendo de declaraciones de personas que habían decidido si donaban los órganos de un familiar en situación de muerte cerebral. Inserto en esta tradición, este trabajo analiza cualitativamente el discurso de seis familias que concedieron la donación de órganos y de tres que la denegaron. Describe la interpretación procesal de esta experiencia e identifica variables y procesos psicosociales que permitan comprender la decisión adoptada. Se identifican dos heurísticos que orientan la decisión familiar ante la petición de donación de órganos: la voluntad manifestada o inferida del fallecido y las actitudes familiares hacia la donación y el trasplante de órganos de los decisores; se postula que la interacción de ambos explica una parte significativa de las decisiones adoptadas. También se hipotetiza que una fuerte discrepancia entre estos dos procesos favorece que otros factores (especialmente la actuación del coordinador de trasplantes y del personal sanitario) adquieran mayor importancia en la decisión familiar. Los resultados apoyan, a nivel social, la aplicación de programas de promoción del trasplante y, a nivel hospitalario, la aplicación de intervenciones que integren técnicas de intervención en crisis y de persuasión y cambio de actitudes.

Palabras clave: estudio cualitativo, donación de órganos, percepción, familias, entrevista
\end{abstract}

This work was carried out with financial support from the Fund for Health Research of the Spanish Minitry of Health and Consumer Affairs, through the project FIS 95/0538.

The authors would like to express their thanks for the collaboration provided by the hospitals that participated in the study and, most particularly, their enormous gratitude to the relatives who agreed to be interviewed at an especially difficult time, such as the process of mourning for the death of a loved one.

Correspondence concerning this article should be addressed to: José Manuel Martínez García, Universidad Autónoma de Madrid, Facultad de Psicología, Ciudad Universitaria Cantoblanco, 28049 Madrid (Spain). E-mail: josemanuel.martinez@uam.es

Translation: Virginia Navascués Howard 
Many efforts have been made to promote organ donation in western countries, although only in Spain has there been a notable and continued increase (Matesanz, 2006; Schütt, 2002). Multidisciplinary research on donation and organ transplant has contributed effectively to extending transplant, necessarily related to obtaining permission to extract the organs of a recently deceased relative (Jacoby, Breitkopf, \& Pease, 2005; Sanner, 2006). Some of the studies on the psychosocial determinants of organ donation have attempted to analyze the opinions and emotions generated by the donation process in the relatives of potential organ donors, in order to identify factors that may facilitate or inhibit granting permission. These investigations have made considerable advances in our understanding of the family perception of organ donation and have promoted the development of specific training processes for transplant coordinators (Matesanz, 2006), the healthcare personnel who are responsible for obtaining the express family consent that makes possible a generous act such as organ donation.

This kind of research began in 1971, with a longitudinal study of 35 families of 14 kidney donors (Simmons, Klein, \& Simmons, 1987) that identified two factors that have been the most frequently cited in subsequent investigations: empathy with kidney patients and the wish to achieve some kind of immortality for the deceased relative. In the 1990s, Savaria, Rovelli, and Schweixer (1990) analyzed the experience of 49 donor families in Hartford (USA) by means of a questionnaire sent by mail: $36 \%$ of these families had talked with the deceased about organ donation, and $63 \%$ did not know the deceased's wishes; the chief reasons for donation were "the deceased wanted to help others" (45\%), "donation adds something positive to death" $(41 \%)$, "donation will give the recipient a better life" $(40 \%)$, "the deceased had expressed the wish to be a donor" (28\%), "the desire for the deceased to live on in someone else" (19\%).

These studies, which were mostly descriptive and with little theoretical basis, evolved in the decade of the 1990s toward investigations that based their choice of variables and hypotheses on diverse theoretical referents. Pelletier (1992, 1993a, 1993b) used the stress and coping model of Lazarus and Folkman (1984) to analyze nine interviews of 7 donor families. From this perspective, the family crisis represented by the organ donation process is structured in three phases or stages: anticipation, confrontation, and post-confrontation. In each phase, the emotions experienced and the coping strategies used are analyzed. In the anticipation phase, the threat to family life and uncertainty about the outcome were the most stressing situations, associated with helplessness, sadness, and mutism. People coped with these negative emotions by searching for information and support (in all the cases analyzed), although escape and avoidance reactions were also present. During the confrontation phase, stress is related to the diagnosis of brain death and to the perception of healthcare personnel's errors, and there are usually reactions of disbelief and shock that the donors try to relieve by granting permission. The post-confrontation stage is characterized by stress related to the loss of a loved one.

Tymstra, Heyink, Pruim, and Slooff (1992) addressed family experience of organ donation by semistructured interviews of 11 families: 5 donors and 6 nondonors. The results show that the deceased's will played an essential role: the existence of a donor's card determined family consent and its absence led the family to deduce the deceased's opposition while alive. The authors emphasize that people are uninformed of the meaning of "brain death" and, therefore, they recommend giving the relatives enough time to prepare for the patient's death and to accept it. Pearson, Bazeley, Spencer-Plane, Chapman, \& Robertson (1995) with a larger and more diverse sample, made up of 69 people (32 donors and 21 nondonors and 16 people who were not requested to donate), reached similar conclusions: the decision to donate was affected by the beliefs about the deceased's desire, although these authors specify that it is either directly (by the existence of a donor's card) or indirectly inferred (because they believe that the deceased was the kind of person who liked to help others).

The most structured model is that of Sque and Payne (1996). Elaborated from the qualitative analysis of 24 interviews of relatives, it proposes a model of "dissonant loss" that considers family behavior the result of a dialectic process of a series of conflicts and the ways to solve them, through various phases. This is displayed in Table 1.

Recently, Jacoby, Breitkopf, and Pease (2005), by means of the focus group technique, analyzed the perceived needs of 11 donor families and 5 nondonors. Both groups expressed similar needs with regard to clear information, emotional support, and the wish to consult someone who had experienced a similar situation who would really understand their anguish and who could interpret the information for them. The main differences between donors and nondonors were: according to the families who refused permission, little prior preparation for the donation request, insufficient time to cope with the crisis and make the decision (in the case of nondonors), and the existence (in the case of the donors) or absence of a person who acted as an intermediary with the doctors who had treated the deceased. They also noted the scarce preparation of the healthcare personnel to attend the families of potential donors. Haddow (2004), in a qualitative study with semistructured interviews of 19 Scottish donor families and 4 nondonors, reached similar conclusions as those of Jacoby and colleagues. Moreover, to increase the likelihood of donation, these authors propose developing emotional support strategies for the families of potential donors, promoting direct early communication, and ensuring the respectful treatment of the deceased's body. In Spain, there have been few studies of family perception of organ donation. At the beginning of the 90s, various research 
Table 1

The Process of Dissonant Loss (Sque \& Payne, 1996)

\begin{tabular}{lll}
\hline \multicolumn{1}{c}{ Phase } & \multicolumn{1}{c}{ Sources of Conflict } & \multicolumn{1}{c}{ Ways of Resolution } \\
$\begin{array}{l}\text { Perception of the } \\
\text { reality of death }\end{array}$ & $\begin{array}{l}\text { Knowledge of the irreversibility of death. Perception } \\
\text { of death. Not knowing how to react. Waiting for } \\
\text { confirmation of brain death. }\end{array}$ & Confirmation of brain death \\
\hline $\begin{array}{l}\text { Confirmation } \\
\text { of brain death }\end{array}$ & $\begin{array}{l}\text { Difficulty of compatibilizing the death with the } \\
\text { apparent life of the relative, maintained artificially. } \\
\text { Lack of knowledge about the procedures to verify } \\
\text { brain death. }\end{array}$ & $\begin{array}{l}\text { Promote trust in the procedures to verify brain death; } \\
\text { facilitate saying goodbye to the deceased before and } \\
\text { after the extraction; avoid making the request until } \\
\text { brain death has been confirmed. }\end{array}$ \\
\hline $\begin{array}{l}\text { Decision to donate } \\
\text { A decision that must be made about donation. } \\
\text { Possible discrepancy between the wishes of the } \\
\text { deceased and one's own wishes. }\end{array}$ & $\begin{array}{l}\text { Knowledge of the will and/or characteristics of the } \\
\text { deceased. Confirmation of brain death. Information } \\
\text { about extraction. }\end{array}$ \\
\hline $\begin{array}{l}\text { Saying goodbye } \\
\text { Coping with } \\
\text { bereavement }\end{array}$ & $\begin{array}{l}\text { Leaving the deceased so it seems he/she has not died. } \\
\text { Esthetic presentation of the body. }\end{array}$ & $\begin{array}{l}\text { Support to cope with the death; contact of the } \\
\text { coordinator with the family after the extraction. } \\
\text { Decision about donation. }\end{array}$ \\
\hline
\end{tabular}

teams analyzed several aspects of the family decision. Domínguez, Murillo, Muñoz, and Pérez (1992) administered a questionnaire of possible reasons for their refusal to the relatives of 31 deceased patients, who had refused the donation request. The authors classified these reasons into four groups: religious/cultural considerations (lack of comprehension of the concept of brain death and aversion to the notion of dissecting the body), circumstantial considerations (incapacity to accept the reality of the death), social considerations (the desire for a traditional funeral and fear of others' criticism), and others (doubts about the usefulness of transplants and about the fair distribution of the organs). Frutos, Blanca, Rando, Ruíz, and Rosel (1994) and Rosel, Frutos, Blanca, and Ruíz, (1995) analyzed the data of a questionnaire completed by 35 families: 22 donors and 13 nondonors. They found total respect (in both types of families) for the deceased's will about donation expressed during life. Concerning the reasons, for the nondonors, the alteration of body esthetics, the integrity of the body, and suspicions about irregularities in the extraction or distribution process were more important. The donors valued the doctor's and nurses' personal treatment more positively, they had a better understanding of the concept of brain death, showed a more favorable attitude toward donation in their immediate environment, and a higher a posteriori degree of agreement with the decision made.

These studies coincide in the importance of the process of requesting organ donation; however, their contribution is limited by the scarcity of procedural studies (particularly in our country) that attempt to offer complex and integrated explanations of the process of organ donation. Qualitative methodology, and specifically, the analysis of discourse constitutes an alternative that allows us to examine in depth the complex and procedural perception (Miles, 1994) in order to generate a contrastable theory of the process of organ donation from the family perspective.

Based on these premises, an exploratory qualitative study with three main goals was developed: (a) to identify the principle psychosocial variables that affect the decision process of granting or denying permission of organ donation by family members who are directly involved; (b) to analyze the interaction of these variables during the process of organ donation; and (c) to propose a model of decision process that can be contrasted by means of quantitative and qualitative methodology.

\section{Method}

\section{Participants}

The sample was made up of 9 families who had received the request to donate the organs of a deceased relative. Three of them had refused permission and six had granted it. The selection of the interviewed families was made by the 
transplant coordinators who had made the request, and who belonged to five clinical centers. The main characteristics of the sample of families interviewed (donors and nondonors) are displayed in Table 2.

\section{Instrument}

The "Entrevista Familiar de Donación de Órganos" [In English, "The Family Organ Donation Interview"], a semistructured instrument, designed for this purpose from the analysis of data from bibliographic sources and prior interviews with 43 transplant coordinators from 34 hospital centers, was used.

Interview Guideline Content. The interview guideline respected the sequential structure of the organ donation process: previous circumstances (admittance in the Intensive Care Unit, communication of the event, information received, etc.), communication of the relative's death (when, by whom, and how it was made, comprehension and acceptance of the death by the family members, reactions, and feelings), the donation request (experience of the interval between the communication of the death and the donation request, by

Table 2

Main Characteristics of the Interviewed Families (Nondonors and Donors) and of the Deceased

\begin{tabular}{|c|c|c|c|c|c|c|}
\hline \multicolumn{7}{|c|}{ NONDONOR FAMILIES } \\
\hline & & & Donation Process & Interview & & \\
\hline $\begin{array}{l}\text { Family / Cause } \\
\text { of refusal }\end{array}$ & $\begin{array}{l}\text { Sex of } \\
\text { deceased }\end{array}$ & $\begin{array}{l}\text { Age of } \\
\text { deceased }\end{array}$ & $\begin{array}{l}\text { Cause } \\
\text { of death }\end{array}$ & $\begin{array}{l}\text { Relatives' socio- } \\
\text { cultural level }\end{array}$ & $\begin{array}{l}\text { Deciders (kinship } \\
\text { with deceased) }\end{array}$ & $\begin{array}{l}\text { Informers (kinship } \\
\text { with deceased) }\end{array}$ \\
\hline $\begin{array}{l}\text { NEG-1 / } \\
\text { Respecting the } \\
\text { deceased's will }\end{array}$ & Male & 59 & Heart failure & Medium-low & $\begin{array}{l}\text { Wife, daughter } \\
\text { and son }\end{array}$ & $\begin{array}{l}\text { Wife and } \\
\text { daughter }\end{array}$ \\
\hline $\begin{array}{l}\text { NEG-2 / } \\
\text { Avoiding family conflict, } \\
\text { beliefs in reincarnation }\end{array}$ & Male & 49 & $\begin{array}{l}\text { Cerebral } \\
\text { hemorrhage }\end{array}$ & $\begin{array}{l}\text { Wife: low. } \\
\text { Daughter: high }\end{array}$ & $\begin{array}{l}\text { Mother, siblings, } \\
\text { wife and daughter }\end{array}$ & $\begin{array}{l}\text { Wife and } \\
\text { daughter }\end{array}$ \\
\hline $\begin{array}{l}\text { NEG-3 / } \\
\text { Ignorance of the deceased's } \\
\text { will. Possible medical } \\
\text { negligence }\end{array}$ & Male & 59 & Work accident & Low & $\begin{array}{l}\text { Wife, sister-in-law } \\
\text { of deceased }\end{array}$ & Wife \\
\hline \multicolumn{7}{|c|}{ DONOR FAMILIES } \\
\hline & & & Donation Process & Interview & & \\
\hline $\begin{array}{l}\text { Family / Cause } \\
\text { of refusal }\end{array}$ & $\begin{array}{l}\text { Sex of } \\
\text { deceased }\end{array}$ & $\begin{array}{l}\text { Age of } \\
\text { deceased }\end{array}$ & $\begin{array}{l}\text { Cause } \\
\text { of death }\end{array}$ & $\begin{array}{l}\text { Relatives' socio- } \\
\text { cultural level }\end{array}$ & $\begin{array}{l}\text { Deciders (kinship } \\
\text { with deceased) }\end{array}$ & $\begin{array}{l}\text { Informers (kinship } \\
\text { with deceased) }\end{array}$ \\
\hline DON-1 & Male & 51 & $\begin{array}{l}\text { Cerebral } \\
\text { hemorrhage }\end{array}$ & $\begin{array}{l}\text { Wife: low } \\
\text { Daughters: medium }\end{array}$ & $\begin{array}{l}\text { Wife, daughter } \\
\text { and son }\end{array}$ & Wife and daughter \\
\hline DON-2 & Female & 11 months & $\begin{array}{l}\text { Drowned } \\
\text { in pool }\end{array}$ & Low & Father and mother & Father and mother \\
\hline DON-3 & Male & 33 & $\begin{array}{l}\text { Cerebral } \\
\text { injury }\end{array}$ & Unknown & $\begin{array}{l}\text { Mother, wife, } \\
\text { and sister }\end{array}$ & Wife and sister \\
\hline DON-4 & Male & 35 & $\begin{array}{l}\text { Cerebral anoxia } \\
\text { from asthma crisis }\end{array}$ & Medium & Wife and father & Wife and father \\
\hline DON-5 & Male & 30 & Heart failure & Medium-high & Wife and father & Father \\
\hline DON-6 & Female & 57 & $\begin{array}{l}\text { Cerebral } \\
\text { hemorrhage }\end{array}$ & Low & Husband and son & Husband and son \\
\hline
\end{tabular}


whom and how it was done, arguments used, information provided, emotional support, reactions, and feelings) and the decision process (family members present, pros and cons of donation, knowledge of and respect for the deceased's will, etc.).

\section{Procedure}

The informers were captured in three stages: first, the research team interviewed the transplant coordinators to request their collaboration. They were sent a protocol in which the criteria to select the families were specified, with suggestions about how to ask for permission for the interview. These criteria referred to the selection of the relatives who were the most responsible for granting or denying donation permission (with a maximum desirable number of three people per interview), between the past 3 and 12 months. Information was also included about the investigation, the content of the interview, and the need to guarantee the confidentiality of the statements was underscored. In the second stage, once the family had agreed to the interview, the coordinator contacted the research team to communicate the identity of the family and to inform them about the indispensable details they should know (about the relatives, the deceased, the circumstances of death, and the donation request interview). In the third stage, an interviewer from the research team contacted the family to schedule the time and place of the interview. The interview was either carried out at the relatives' home (6) or at the reference hospital (3), depending on the families' wishes. The interviews were recorded on magnetic support, after the families had given their consent. A protocol of data collection to be completed by the interviewer was elaborated if the family did not agree to recording (this occurred on two occasions). The tapes were literally transcribed. The interviews lasted between 40 and 75 minutes (on average, 58 minutes).

\section{Analysis of the Results}

Discourse analysis was conducted in order to study in depth the processes that intervene in the family's decision and to identify new processes, factors, or variables that affect it. For this purpose, the analysis was structured procedurally, according to the interview guideline. The statements of the interviewees were included in each of the components that made up the interview. To analyze this structured material, we used a syncretic perspective, based on the "grounded theory" (Glaser \& Strauss, 1967), to discover processes or variables and relations among them (Strauss \& Corbin, 1990), and on "analytic induction" to verify and partially or universally generalize (Taylor \& Bodgan, 1984). There were two main axes of analysis: longitudinal or procedural (to examine the process of organ donation) and crosssectional or discriminant (to compare donor and nondonor families). The comparative constant method (Álvarez-Gayou, 2003) was applied to generate provisional inferences, which agreed with the opinions expressed by the interviewed relatives. Each new statement about a same topic (by the same interviewee or the rest of the informers) was compared to the previous hypotheses to estimate its theoretical coherence. When discordances were observed, we reformulated the hypothesis to include this new perspective. If this were not possible, the universe of content of the interviewees was classified or structured, assuming the existence of different perceptions about the topic. As a result of this process, some universal and some partial hypotheses were established. A hypothesis is considered universal or invariant if it fulfills two conditions: (a) it finds concrete empirical support in all the statements of all the subjects; (b) there is no statement that invalidates or partially disconfirms it. A partial hypothesis includes diverse perceptions about a specific aspect of the interview, even if there is only one statement whose content differs from the previous statements.

Quality controls. All the analyses were performed by a single team member. This member's conclusions and the original material (interviewees' statements structured into blocks of topics) were reanalyzed by another three team members, whose mission was to refute, with empirical support, the conclusions of the first researcher. Lastly, the consensual conclusions were contrasted with the results of preceding research, as can be seen in the Discussion section.

The qualitative analysis was performed using the qualitative analysis computer program NUDIST (NonNumerical Unstructured Data Indexing Searching and Theorizing).

\section{Results}

\section{Knowledge of and Family Attitude to Organ Donation and Transplant}

Tables 3 and 4 display the previous attitudes to organ donation and transplant in the families who refused permission and those who granted permission, respectively. In the first rows of each table (in boldface) are the main deciders who intervened in the decision.

\section{Family Perception at the Beginning of the Crisis}

All the interviewees acknowledge the admission to the hospital of the potential donor as the beginning of the emergency situation process (illness or accident). The most well remembered and valued detail of this stage was the speed of the intervention, and at a second level, the information provided to the relatives about the patient and the treatment. In all cases, except for two (NEG-3 and DON4 ), the patient's relatives considered the actions of the 
Table 3

Attitudes to Organ Donation and Transplant of Nondonor Families

\begin{tabular}{|c|c|c|c|}
\hline & \multicolumn{3}{|c|}{ FAMILIES / SURVIVING RELATIVES } \\
\hline & $\begin{array}{l}\text { NEG-1 / } \\
\text { Wife, daughter }\end{array}$ & $\begin{array}{l}\text { NEG-2 / } \\
\text { Wife, daughter, mother, siblings }\end{array}$ & $\begin{array}{l}\text { NEG-3 / } \\
\text { Wife, sister-in-law }\end{array}$ \\
\hline $\begin{array}{l}\text { Prior information about organ } \\
\text { donation and transplant }\end{array}$ & $\begin{array}{l}\text { Wife: very little. } \\
\text { Daughter: yes }\end{array}$ & $\begin{array}{l}\text { Wife: yes, positive. } \\
\text { Daughter: yes, positive. } \\
\text { Mother: ? } \\
\text { Siblings: ? }\end{array}$ & $\begin{array}{l}\text { Wife: no } \\
\text { Sister-in-law: no }\end{array}$ \\
\hline $\begin{array}{l}\text { Did they know any donors or } \\
\text { recipients of transplanted organs? }\end{array}$ & $\begin{array}{l}\text { Wife: no } \\
\text { Daughter: no }\end{array}$ & $\begin{array}{l}\text { Wife: yes } \\
\text { Daughter: no } \\
\text { Mother:? } \\
\text { Siblings: ? }\end{array}$ & $\begin{array}{l}\text { Wife: no } \\
\text { Sister-in-law: no }\end{array}$ \\
\hline $\begin{array}{l}\text { Prior attitude of each decider } \\
\text { o organ donation }\end{array}$ & $\begin{array}{l}\text { Wife: negative } \\
\text { Daughter: negative }\end{array}$ & $\begin{array}{l}\text { Wife: positive } \\
\text { Daughter: positive } \\
\text { Mother: negative } \\
\text { Siblings: negative }\end{array}$ & $\begin{array}{l}\text { Wife: none } \\
\text { Sister-in-law: none }\end{array}$ \\
\hline $\begin{array}{l}\text { Deceased's will with regard } \\
\text { to organ donation }\end{array}$ & $\begin{array}{l}\text { Negative (inferred } \\
\text { by the family) }\end{array}$ & Positive & Unknown \\
\hline Main cause of refusal & $\begin{array}{l}\text { Respect for the } \\
\text { deceased's will. } \\
\text { Poor information. }\end{array}$ & Family conflict & $\begin{array}{l}\text { Lack of knowledge of deceased's } \\
\text { will: Horror of mutilation. Poor } \\
\text { medical attention. }\end{array}$ \\
\hline
\end{tabular}

Table 4

Attitudes to Organ Donation and Transplant of Donor Families

\begin{tabular}{|c|c|c|c|c|c|c|}
\hline & \multicolumn{6}{|c|}{ FAMILIES / SURVIVING RELATIVES } \\
\hline & $\begin{array}{l}\text { DON-1 / } \\
\text { Wife, daughter, } \\
\text { mother }\end{array}$ & $\begin{array}{l}\text { DON-2 / } \\
\text { Father, mother }\end{array}$ & $\begin{array}{l}\text { DON-3 / } \\
\text { Wife, sister, } \\
\text { mother }\end{array}$ & $\begin{array}{l}\text { DON-4 / } \\
\text { Wife, father }\end{array}$ & $\begin{array}{l}\text { DON-5 / } \\
\text { Wife, father }\end{array}$ & $\begin{array}{l}\text { DON-6 / } \\
\text { Father, son }\end{array}$ \\
\hline $\begin{array}{l}\text { Prior information } \\
\text { about organ donation } \\
\text { and transplant }\end{array}$ & $\begin{array}{l}\text { Wife: positive } \\
\text { Daughter: positive } \\
\text { Mother:? }\end{array}$ & $\begin{array}{l}\text { Father: none } \\
\text { Mother: none }\end{array}$ & $\begin{array}{l}\text { Wife: positive } \\
\text { Daughter: positive } \\
\text { Mother: negative }\end{array}$ & $\begin{array}{l}\text { Wife: positive } \\
\text { Father: positive }\end{array}$ & $\begin{array}{l}\text { Wife: positive } \\
\text { Father: little }\end{array}$ & $\begin{array}{l}\text { Father: none } \\
\text { Daughter: positive }\end{array}$ \\
\hline $\begin{array}{l}\text { Did they know any } \\
\text { donors or recipients } \\
\text { of transplanted organs? }\end{array}$ & $\begin{array}{l}\text { Wife: yes } \\
\text { Daughter: yes } \\
\text { Mother: no }\end{array}$ & $\begin{array}{l}\text { Father: none } \\
\text { Mother: none }\end{array}$ & $\begin{array}{l}\text { Wife: yes } \\
\text { Daughter: yes } \\
\text { Mother: no }\end{array}$ & $\begin{array}{l}\text { Wife: yes } \\
\text { Father: yes }\end{array}$ & $\begin{array}{l}\text { Wife: none } \\
\text { Father: none }\end{array}$ & $\begin{array}{l}\text { Father: yes } \\
\text { Daughter: no }\end{array}$ \\
\hline $\begin{array}{l}\text { Prior attitude of } \\
\text { each decider to } \\
\text { organ donation }\end{array}$ & $\begin{array}{l}\text { Wife: positive } \\
\text { Daughter: positive. } \\
\text { Mother: none }\end{array}$ & $\begin{array}{l}\text { Father: none } \\
\text { Mother: none }\end{array}$ & $\begin{array}{l}\text { Wife: positive } \\
\text { Daughter: positive } \\
\text { Mother: no }\end{array}$ & $\begin{array}{l}\text { Wife: positive } \\
\text { Father: positive }\end{array}$ & $\begin{array}{l}\text { Wife: positive } \\
\text { Father: none }\end{array}$ & $\begin{array}{l}\text { Father: positive } \\
\text { Daughter: none }\end{array}$ \\
\hline $\begin{array}{l}\text { Deceased's will with } \\
\text { regard to organ } \\
\text { donation }\end{array}$ & $\begin{array}{l}\text { Positive } \\
\text { (11-month } \\
\text { old child) }\end{array}$ & None & Negative* & Positive & $\begin{array}{l}\text { Positive } \\
\text { (inferred } \\
\text { by family) }\end{array}$ & $\begin{array}{l}\text { Positive } \\
\text { (inferred } \\
\text { by family) }\end{array}$ \\
\hline $\begin{array}{l}\text { Main cause of granting } \\
\text { permission }\end{array}$ & $\begin{array}{l}\text { Respect for } \\
\text { deceased's will }\end{array}$ & $\begin{array}{l}\text { To save the life } \\
\text { of another child }\end{array}$ & $\begin{array}{l}\text { Thinking that some } \\
\text { part of him will stay } \\
\text { alive. Moral duty. }\end{array}$ & $\begin{array}{l}\text { To help others. } \\
\text { He will live } \\
\text { on in others. }\end{array}$ & $\begin{array}{l}\text { To save lives. } \\
\text { Do what he would } \\
\text { have wished. }\end{array}$ & $\begin{array}{l}\text { Usefulness. Moral } \\
\text { duty. Respect } \\
\text { for her will. }\end{array}$ \\
\hline
\end{tabular}

Note. $\left.{ }^{*}\right)$ The deceased had stated in life that he did not want to donate because he was afraid they would hasten his death. But the family said that they could verify this was an unjustified fear. The family believed that, in these conditions, the deceased would have agreed to the request. 
medical service at the onset of the emergency to be positive. The mobilization of a large number of doctors and nurses, the swiftness of the diagnostic tests, and the professionals' nonverbal language (gestures of concern, tension, fast movements, etc.) were interpreted as examples of effort, competence, and professional dedication.

DON-1: “At the time, you don't realize it, but when you see that everyone has acted quickly, they gave him hundreds of injections, they inserted a cannula, they did artificial respiration, you know they have tried their best and... well (begins to cry)... nothing could be done. Later, you don't say anything, but you are thankful."

\section{The Relationship with the Professional Healthcare Personnel during the Crisis}

All the donor families considered the information they received was clear and direct right from the start; they were not offered hope of their relative's recovery and (on two occasions), they even were told that, "if, by some miracle, he survives, he would be like a vegetable." At the beginning, these statements, which were to inform them about the patient's evolution, seemed "cruel," but when the donation process was over, they were positively valued because the family's awareness of the severity of the situation allowed them to accept their relative's death more easily and quickly. The three families who refused donation valued the relation with the health personnel negatively because of its coldness, hardness and prepotency. Moreover, either by action (not emphasizing the severity of the situation) or omission (no comments were made so they assumed that their relative would overcome the crisis), they had raised their hopes, only to be disappointed later, and this led them to suspect that the healthcare personnel had not done all they could.

NEG-2: "I'm sorry, but I still believe that they did not know how to tell us what was going on...maybe they did not know, but when you are in such a situation, if they don't speak clearly, you raise your hopes. Look..., as time goes by and there is no news, people hang on to their hopes."

\section{Communication of the Death}

The relatives who received clear, direct, and progressive information about the patient's deterioration interpreted the death as the confirmation of an expected tragedy. Acceptance of the relative's death was easier for the donors and is closely associated with the doctors' precision when informing them of the patient's critical status. In contrast, the deceased's wife in the family NEG-3 said that her first reaction was disbelief, because they had told her that it was not so severe as they had thought at the beginning, of impotence and guilt for not having insisted much more strongly on better clinical attention. In this case, the medical personnel were held responsible. In the case of the family NEG-1, the initial request was made to the patient's wife, despite having been notified that confirmation of brain death had to wait for a "laboratory analysis of the remains of a medication that was administered to the patient when he was admitted." The closest relative (the wife) of the family NEG-2 considered that the information received was correct and clear and she was inclined to donate but, as we shall see, the decision was made by the patient's mother, who had very negative prior attitudes to donation for religious reasons.

\section{The Family Interview: Requesting Permission to Donate}

All the relatives interviewed, donors and nondonors, indicated that the request for permission was made immediately after the communication of the patient's death. The nondonor relatives, NEG-1 and NEG-3, considered such a quick approach to be very negative, without their having been able to assimilate the news yet, which increased their anxiety and made them feel uncomprehended.

NEG-1: It didn't seem to be the right time or way to do it, [...] this hurt my feelings somewhat. [..] Truly, this was like a bombshell to me.

NEG-3: At that time, I didn't understand a thing. I couldn't believe that my husband had died. I didn't expect them to ask for his organs.

The selection of the main deciders seems to be an important factor. In all the interviews with a negative result, the coordinators either encouraged the participation in the decision process of relatives who were contrary to donation and/or they avoided the contribution of direct relatives who favored donation. For example, among the family members of the family NEG-1 was the deceased's son, who was an organ donor but who did not participate in the consultation because, at that time, he was not in the hospital. In the case of the family NEG-2, the coordinator let all the relatives of the deceased participate, among them, the deceased's mother, who believed in reincarnation and who was the leader of those who opposed donation. In the case of the NEG-3 family, the coordinator did not allow the deceased's daughter, who was an organ donor, to participate, considering that it was better to address the topic with the mother and the elder daughter. In all the interviews that concluded in donation, at least one person was found among the main deciders who was in favor of donation, and there was nobody who maintained the opposite viewpoint a priori.

Respect for the positive will of the deceased was the main criterion that the donor families used to make their decision. Moreover, their decision was congruent with the personal opinion of all the relatives present in the decision process. Under these conditions (positive will of the deceased known by a decider and positive attitudes to donation in a participant in the interview), the doubts or lack of knowledge about the topic of some relative who was undecided or 
reluctant to donate seem to have been easily and quickly resolved by the arguments of the other relatives, with no intervention by the coordinator. In the cases where this did not occur, this rule of broad acceptance could at times be reinterpreted as a function of the family deciders' attitudes. Of particular interest is the case of the family DON-3, where two of the three deciders, the deceased's wife and sister, were clearly in favor of donation, whereas his mother was clearly opposed. In contrast, the known attitude of the deceased was against donation; the favorable deciders intervened directly to convince the deceased's mother, arguing that "his organs are no good to him and there are many people who need them." The coordinator's action attempted to dissipate the mother's doubts about the possibility that her son was not dead; complementarily, the deceased's wife and sister said they had relativized the importance of the reasons for not donating, centered on the fear that they might "remove his organs too soon."

DON-3: We didn't do anything against his will. It was not in writing. He told me that he "wouldn't like them to remove anything because they do it too soon" [..]; but we didn't think about that; he was sick for five days and they didn't ask us before; I know they request it at the right time.

Other positive decisions seem to be due to the coordinator's skill. In the case of the parents of the family DON-2, who had just been informed of the death of their 11-month old daughter (who drowned in a swimming pool), the donation request was made immediately after this communication. The father's first reaction was positive, but the mother refused to donate, imagining that they were going to "wreck the girl's body." The father believed he should leave the final decision to his wife at that time and, for over an hour, the mother did not change her mind. In this interval, the coordinator did not intervene; however, he did intervene later directly and effectively: "he told me that another child needed the transplant urgently, and I thought about my other daughter; some day, she might need an organ and I would be hoping they would agree." After making the decision, "we felt very relieved, thinking about the child who needed the transplant."

With regard to the nondonor families, the deceased's opposition (NEG-1) or the ignorance of the deceased's will (NEG-3) was an important criterion in the decision finally adopted, although other already mentioned factors, favored denying permission. Concerning the family NEG-3, the deceased's wife was responsible for the final decision; the request was made immediately after communicating the patient's death in the hall of the hospital, and this had a devastating effect on the woman's precarious emotional balance. She still remembers that she had not yet managed to assimilate or accept an unexpected death for which she was not previously prepared. This perception, along with the absence of other relevant criteria (she did not know her husband's will and neither she nor any other family member was inclined to donate) determined the refusal of permission. She remembers the coordinator's argument that "it would be good for other people," listing the useful organs, but all she saw was "my husband's body taken to pieces." Moreover, as mentioned, the daughter, who was in favor of donation, was left out of the consultation by the coordinator's instructions.

Lastly, the family NEG-2 thought that the coordinator's decision to include all the relatives, friends, and neighbors present in the decision process was an error. The closest relatives (deceased's wife and daughter) were personally favorable to donation and they knew the deceased's positive will. They intended to donate the organs despite having had some problem with the health services. However, not even with the coordinator's help could they convince the deceased's mother, who was supported by her direct relatives (children), who insisted that extracting the organs would prevent the deceased's reincarnation. The conflict between the two family sectors was made worse because of the hysterical behavior (shouting, hitting the table, etc.) of the main opposer. The deceased's wife and daughter and the coordinator tried by various means to convince her but at no time was the deceased's will to donate expressed. His relatives did not remember it and the coordinator did not ask. The expectation of a big conflict with important consequences (the daughter's studies were being paid for by her grandmother) forced the relatives to give in and refuse donation.

\section{The Decision Process}

In all cases, the final decision was made by the women of the family, independently of whether or not there were any men present, except for the family DON-6, where permission was granted by the deceased's son and husband. A large part of this female protagonism corresponds to the fact that the deceased, in seven of the nine cases, was male, although the interviewees say that, from the start, they felt directly responsible because of their condition of wives and mothers. The decision process was difficult and uncomfortable for most of the interviewees, especially if they felt pressed by the coordinator:

NEG-1: I felt it was like having to cope with an added problem.

NEG-3: It was one of the hardest moments, you want to keep on going until the end but you know you can't, either you make up your mind or the organs are lost, you are racing against time and that is the hardest part.

DON-4: we felt pressed by the coordinator's haste.

When deliberating, each donor family considered various reasons: usefulness ("everyone should do this because, seeing as the organs are no use to the deceased, three or four organs can save many lives," DON-6), generosity ("we could help others," DON-4; "save human lives," DON-5), reciprocity ("I thought about my other daughter and that she might need an organ some day," DON-2), transcendence ("she can live 
on in another person," DON-2), but the central argument or idea that predominated in all the discourses was the "respect for the deceased's will." There were also some emotional processes of empathy with other children, potential recipients of their daughter's donation (DON-2).

The reasons for refusing donation also referred to the deceased's will, either negative (DON-1) or unknown (DON3 ), to which are added other causes such as lack of previous information about donation and transplant, inadequate treatment of the deceased (DON-1), a suspicion of medical negligence, and a horror of the notion of a mutilated corpse (DON-3). On the other hand, except for the family DON6 (which considered their decision to be unalterable), the interviewees thought they might have changed their mind if other conditions had prevailed. The conditions for refusing donation mentioned by the donor families refer mainly to some of the coordinator's or the health personnel's behaviors that they would have considered unacceptable:

DON-1: Perhaps if they had prevented us from seeing him.

DON-2: For lack of attention, contempt, or bad treatment by the doctors, especially because they say they are used to people not looking askance at them [note: probably means "looking askance at the relatives"] because they cannot dress well, because their economical situation does not allow it.

DON-3: If we hadn't trusted the doctors or if they had made the request a day sooner, when there was still some hope.

DON-4: If we had noted excessive interest to get the organs, forcing the decision.

DON-5: We were about to lose patience with the doctors, they are always in such a hurry, they are insensitive, they are so cold, so snobby...like crows.

Lastly, all the families who denied permission mentioned some of the conditions that could have facilitated donation:

NEG-1: More prior information about these topics. More information so we wouldn't have raised our hopes.

NEG-2: They should have only told us-he (the coordinator) shouldn't have let everyone in; the deceased's wife and daughter were present.

NEG-3: I don't believe I would ever have donated. Maybe if they had treated us well and informed us properly...Maybe if they had let my daughter in, she was in favor of it.

\section{Discussion}

\section{Family Attitudes, Heuristics, and Organ Donation}

The family decision about organ donation can gestate before the brain death of a relative in a hospital center. The recent proliferation of information about organ donation and transplant in the mass media and the direct involvement of many families in these matters-either as beneficiaries or as donors-has facilitated the development of personal and family attitudes to these issues in a substantial part of the Spanish public opinion. One consequence of this widespread national debate may be more family knowledge of the personal will to either donate or not donate organs.

A stable relation has been identified between information about these issues, knowledge of donors and recipients, previous attitudes of the family and the deceased to donation and transplant, and the final decision adopted. Firstly, the importance of respecting the deceased's will, indicated by various authors, is confirmed (Frutos et al., 1994; Pearson et al., 1995; Rosel et al., 1995; Sque \& Payne, 1996) but with an important qualification: the deceased's opinion can interact subtly with family attitudes. Thus, the probability of granting permission is partially determined by the beliefs and attitudes of the family and the potential donor, so that the more positive the beliefs and the more clearly known the donor's will, the higher the probability of obtaining the donation, independently of hospital or medical factors. In most cases, these family attitudes were acquired previously, and in other cases, they are the result of the critical situation, generally because of the information provided by the coordinator. Complementarily, the situation of crisis, lack of experience, information overload, lack of emotional control, and the time pressure to make a decision are all conditions that inhibit rational analysis of the decision and are optimal conditions to resort to "heuristics" (Tversky \& Kahneman, 1980) - quick decision rules or mental shortcuts that have an important emotional charge and are not very conscious - as the first way to reach a decision. Given these premises, it could be hypothesized that the personal family attitudes and the deceased's will represent the main heuristics when faced with the request for organ donation. Their congruence seems to determine the final decision with remarkable ease, and the coordinator's intervention is not determinant in such cases. However, when they are in conflict, the coordinator's action may be more important. Thus, for example, in the cases in which the deceased's will cannot be interpreted clearly, family attitudes can become more salient informatively to reach a decision. If there are no family attitudes or they are not easily recoverable, the coordinator's action can establish them. This is compatible with reinterpreting the deceased's statements to make them concur with the deciders' opinions. Corollary to this is the fact that knowledge of prior family attitudes to organ donation and transplant are an important way for coordinators to exert their influence.

The influence of intrafamily conflicts. The absence of conflicts (implicit or manifest) in the first opinions expressed by the relatives who are directly involved in the decision promotes their making a decision quickly and simply. The presence of disparity of criteria promotes a negotiation that may increase the emotional charge of the situation. In these cases, a viewpoint that is firmly against donation, expressed and maintained by some of the deciders, seems to induce 
an undesirable conflict that can be resolved by the yielding of the people who favored donation, now led by the need of not adding more anxiety, especially in the more direct relatives or in those who are more emotionally affected.

The pattern of refusal. It was possible to identify a sequential pattern of conditions that can preclude a donation and that essentially coincide with the experiences described by the three families who refused to donate: considering that the information was not clear or that it was given in a cold, hard, and prepotent way; moreover, either by action (not emphasizing the severity of the situation) or by omission (not telling the family members anything, so they assumed that their relative would overcome the crisis), they were led to raise their hopes, which were later let down, and this made them suspect that not all measures had been taken. This phenomenon of cognitive consonance (Festinger, 1957), which implies the interpretation of reality according to one's personal expectations, occurs much more frequently in situations of high ambiguity and/or crisis. It does not necessarily determine a positive thinking bias, as in this case, but it frequently does produce distortion according to one's prior beliefs and feelings (optimistic or pessimistic), the most direct, important and available source of information (and sometimes the only one possible).

Main elements of the family decision. The donors emphasize their conscious and active participation (they internalize the cause) in organ donation (in many cases, despite the circumstances and the actions of healthcare personnel), and also in spite of the fact that they all (except in the case of the 11-month old girl who died) admit they let themselves be decisively guided by the deceased's opinion (positive in all cases, although inferred in some) when making their decision. In contrast, the nondonor families, currently aware of the popularity of donors, identify several external causes for which they were not responsible and over which they had no control (lack of information about the deceased's evolution and about organ donation and transplant, deficient treatment by the doctors, inadequate action of the coordinator, etc.) that determined their refusal.

Relation with healthcare personnel. Establishing a good relation with the healthcare personnel generates a positive climate and may affect subsequent donation request. Professionals' clarity and the frequency with which they report the potential donor's evolution are much valued; moreover, such conditions seem to facilitate the perception of the inevitability of the demise, they speed up acceptance of death and decrease the negative impact of the persistence of vital signs in the potential donor, one of the most frequently cited factors in the specialized literature (Pearson et al., 1995; Pelletier, 1993b; Tymstra et al., 1992). The incidence of conflicts with the healthcare personnel in the final decision is considerably higher when the family is not clearly inclined toward organ donation. In these cases, the perception of negligence or lack of attention to the patient, insufficient or deficient information about the patient's evolution, and inadequate treatment of the relatives are the main causes of dispute.

The consequences of stress during the request interview. The results of previous research (Sque \& Payne 1996; Savaria et al., 1990) are unclear. In our case, we can hypothesize that stress produced by the request can have both positive and negative effects, depending mainly on three factors: the main deciders' inclination toward donation and their knowledge of the potential donor's will and the coordinator's justification of the eventual added time pressure. When the prior attitudes of the deceased and the families coincide, stress will probably facilitate a fast and simple response in the direction of these feelings. However, stress may hinder the decision process when the most relevant informative elements are dissonant (for example, when the attitudes of the family are different from those of the deceased).

Coordinators' strategies. The arguments and strategies used by coordinators should be adapted to the prior attitudes of the relatives and the deceased so that they offer relevant arguments to the deciders to facilitate their task. Appeals to solidarity or generosity (too abstract) or arguments that anticipate future positive consequences for the donors (consolation, social support, etc.) should not be considered universal strategies if they are not congruent with the deciders' feelings. The desirable consonance between the coordinator's arguments and the deciders' attitudes should be based on extensive knowledge of the characteristics of the family, and it might be better to postpone the donation request until determining some important aspects about the attitudes of the people who will receive the request. The most efficient arguments are usually those used by some family members to convince other members, especially if the former have some authority or are leaders.

Lastly, the data collected allow us to postulate that the efficacy of the transplant coordinator, in those cases where the decision was not previously adopted, can be notably improved with specific training in crisis intervention techniques (Rubin \& Bloch, 1998). Such techniques integrate into a single action the processes of communication of the death, acceleration of bereavement, and emotional support for the families, with persuasion and attitude change (Baron \& Byrne, 2005).

Crisis intervention techniques (see the recent works of Fernández Liria \& Rodríguez Vega, 2002; Fernández Millán, 2005) can be adapted and applied in two main stages of the donation process: in the process of bereavement and when making the donation request. With regard to the bereavement process, progress until reaching the stage of acceptance of the relative's death is a necessary condition to address the donation request (Jacoby et al., 2005; Martínez et al., 2001; Pelletier, 1992). This can be accelerated implicitly by means of asking the main deciders to express their feelings about the deceased, encouraging the relatives and friends to talk about the deceased, to share memories, and especially by means of a farewell ritual (for example, saying goodbye in 
the presence of the corpse, family prayer, or a minute's silence) that publicly sanctions the new situation. Concerning the stage of organ donation request, it is probably useful to adapt the tactics used to correctly address two main types of reactions: dilated or constrained (in the words of Rubin $\&$ Bloch, 1998). In the case of dilated reactions, techniques of emotional self-control or diaphragmatic breathing control and concentrating on specific problems are useful. In the case of constrained reactions, the expression of feelings, attention to other relatives, and helping to design alternative actions should be promoted as much as possible. Complementarily, it is ethically appropriate and pragmatically correct for the crisis intervention process to be prolonged beyond the granting or refusal of permission to donate. To carry out this goal efficiently will require promoting the collaboration among the medical personnel and psychologists specialized in this field, whose task should also include the relatives of deceased nondonors.

Adapting contemporary persuasion techniques (see Albarracín, Johnson, \& Zanna, 2005; or Pratkanis, 2007) to this problem may increase the number of donations in families that have serious doubts about this decision. Among other tactics, from a rational perspective, the coordinators should match their arguments to the most obvious characteristics of the main deciders (emotional or rationalist, religious or secular). And from a heuristic and emotional perspective, they should promote self-persuasion (for example, by asking how the organs will be used, inquiring about the qualities of the deceased and relating them to organ donation, and getting relatives who favor donation to collaborate), as well as use techniques based on the emergence of the reciprocity rule (giving in to their arguments, simplifying the burial formalities, or showing concern about the health of the relatives who are the most affected, without linking this explicitly to the donation request).

Donating organs for transplants is a complex issue whose interdisciplinary study furthers its more extensive and realistic comprehension. Qualitative studies with donor and nondonor families, in addition to gaining insight about the interpretation of this situation made by the main protagonists, provides material of remarkable significance in order to adapt our psychological knowledge to the complicated task of promoting a prosocial behavior that is so important to increase the expectation and quality of life.

\section{References}

Albarracín, D., Johnson, B.T., \& Zanna, M.P. (2005): The handbook of attitudes. Mahwah, NJ: Erlbaum.

Álvarez-Gayou, J.L. (2003). Cómo hacer investigación cualitativa. Fundamentos y metodología. México: Paidós Educador.

Baron, R.A., \& Byrne, D. (2005). Social psychology (10 ${ }^{\text {th }}$ ed.). Boston: Allyn \& Bacon. [Spanish translation: Psicología social (10 a ed.). Madrid: Pearson-Prentice Hall, 2005].
Domínguez, J.M., Murillo, F., Muñoz, A., \& Pérez, M.A. (1992). Psychological aspects leading to refusal of organ donation in southwest Spain. Transplantation Proceedings, 24, 25-26.

Festinger, L. (1957): A theory of cognitive dissonance. Evanston, Ill: Row Peterson.

Fernández Liria, A., \& Rodríguez Vega, A. (2002). Intervención en crisis. Madrid. Síntesis.

Fernández Millán, J.M. (2005). Apoyo psicológico en situaciones de emergencia. Madrid. Pirámide.

Frutos, M.A., Blanca, M.J., Rando, B., Ruíz, P., \& Rosel, J. (1994). Actitudes de las familias donantes y no donantes de órganos. Revista Española de Trasplantes, 3, 163-169.

Glaser, B.G. \& Strauss, A.L. (1967). The discovery of grounded theory: Strategies for qualitative research. Chicago: Aldine Publishing Company.

Haddow, G. (2004). Donor and nondonor families' accounts of communication and relations with healthcare professionals. Prog Transplant, 14, 41-48.

Jacoby, L.H., Breitkopf, C.R., \& Pease, E.A. (2005). A qualitative examination of the needs of families faced with the option of organ donation. Dimensions of Critical Care Nursing; Jul/Aug, 24, 183-189.

Lazarus, S.R., \& Folkman, S. (1984). Stress, appraisal and coping. New York: Springer.

Martínez, J.M., López, J.S., Martín, A., Martín, M.J., Scandroglio, B., \& Martín, J.M. (2001). Organ donation and familiy decisiontaking within the Spanish donation system. Social Science, \& Medicine, 53, 405-421.

Matesanz, R. (2006). El milagro de los trasplantes. De la donación de órganos a las células madre. Madrid: La Esfera de los Libros.

Miles, M.B. (1994). Qualitative data analysis. Thousand Oaks, CA: Sage.

Pearson, I.Y., Bazeley, P., Spencer-Plane, T., Chapman, J.R., \& Robertson, P. (1995). A survey of families of brain dead patients. Their experiences, attitudes to organ donation and transplantation. Anaesthesia and Intensive Care, 23, 8895.

Pelletier, M. (1992). The organ donor family members' perception of stressful situations during the organ donation experience. Journal of Advanced Nursing, 17, 90-97.

Pelletier, M. (1993a). The needs of family members of organ and tissue donors. Heart and Lung, 22, 151-157.

Pelletier, M. (1993b). Emotions experienced and coping strategies used by family members of organ donors. Canadian Journal of Nursing Research, 25, 63-73.

Pratkanis, A.R. (2007). The Science of social influence: Advances and future progress. New York: Psychology Press.

Rosel, J., Frutos, M.A., Blanca, M.J., \& Ruíz, P. (1995). La decisión de donar órganos. Variables contextuales y consecuencias de la decisión. Psicothema, 7, 605-618.

Rubin, B., \& Bloch, E. (1998). Crisis intervention and trauma resonse. Theory and practice. New York: Springer. [Spanish translation: Intervención en crisis y respuesta al trauma. Teoría y práctica. Bilbao: Desclée de Brouwer, 2001]. 
Sanner, M. (2006). People's attitudes and reactions to organ donation. Mortality, 11, 133-150.

Savaria, D.T., Rovelli, M.A., Schweixer, R.T.(1990). Donor family surveys provide useful information for organ procurement. Transplantation Proceedings, 22, 316-317.

Schütt, G.R. (2002). 25 years of organ donation: European initiatives to increase organ donation. Transplantation Proceedings, 34, 2005-2006.

Simmons, R.G., Klein, S.D., \& Simmons, R.L. (1987). Gift of life: The social and psychological impact of organ transplantation. New York: Wiley.

Sque, M., \& Payne, S.A. (1996). Dissonant loss: The experiences of donor relatives. Social Science and Medicine, 43, 1359-1370.

Strauss, A., \& Corbin, J. (1990). Basics of qualitative research: Grounded theory procedures and techniques. London: Sage.
Taylor, S. J., \& Bodgan, R. (1984). Introduction to qualitative research methods. The search for meanings. New York: Wiley. [Spanish translation: Introducción a los métodos cualitativos en investigación. Barcelona: Paidós Básica, 1997].

Tversky, A., \& Kahneman, D. (1980). Casual schemas in judgements under uncertainty: Heuristics and biases. In M. Fishbein (Ed.), Progress in social pyschology (pp. 49-72). Hillsdale, NJ: Erlbaum.

Tymstra, T., Heyink, J.W., Pruim, J., \& Slooff, M.J. (1992). Experience of bereaved relatives who granted or refused permission for organ donation. Family Practice, 9, 141-144.

Received July, 11, 2006

Revision received May, 10, 2007

Accepted June, 26, 2007 